Independent Journal of Management \& Production (IJM\&P) ISSN: 2236-269X

DOI: 10.14807/ijmp.v3i2.46

v. 3, n. 2, July - December 2012

\title{
THE FUNCTION AT SOCIETY OF THE SPIN-OFFS ACADEMICS ACTING AS A MECHANISM FOR TECHNOLOGY TRANSFER
}

Lourenço Santos Dantas Gomes Federal Technological University of Paraná - Brazil

E-mail: lourencodantas@hotmail.com

Pedro Paulo Andrade Junior Federal Technological University of Paraná - Brazil E-mail: pedropaulo@utfpr.edu.br

João Luiz Kovaleski Federal Technological University of Paraná - Brazil E-mail: kovaleski@utfpr.edu.br

Submission: 10/12/2012 Accept: $11 / 12 / 2012$

\begin{abstract}
:
This article aims to present a theoretical review of the process of technology transfer between universities and companies, focusing on the technology-based companies, specifically academic spin-offs as one of the main tools for technology transfer. It then made a presentation on the importance of factors such as skilled human resources, encouraging the government as an agent, technological innovation, and Innovation Act (2004) for the transferring. The methodological approach of this paper is characterized as a basic research, qualitative, exploratory and technical procedures as a literature search. The research resulted in the realization that the technological development model based on cooperation between universities and companies has been consolidated as one of the strategies of technological and economic development of the country, as seeking to bring differential factors of competitiveness in the market.
\end{abstract}

Key-words: Spin-Off, Technology Transfer, Technology innovation, Knowledge transfer.

\section{Introduction}

During a long time the relationship of technology transfer between UniversityCompany relied just in skilled labor from university to a specific function at company, however, with the encouragement of Brazilian government to technology innovation 
Independent Journal of Management \& Production (IJM\&P) ISSN: 2236-269X

this relationship is intensifying. A test is the regulation of Innovation Law.

Currently we live a society characterized by a knowledge-based economy, or learning-based economy (JOHNSON and LUNDVALL, 2005), where technological development depends directly on the formation of qualified human resources, however it is not only focused on production that need this training, after technology development is focused on the company and one of the main problems is the impact and influence that these new technologies cause due to the culture of the environment in which it is imposed. In this sense, claim that knowledge is a major, or even the main resource for organizational environments that innovate and remain competitive.

Knowledge utilization is a large field of inquiry that crosses disciplines and encompasses multiple theoretical backgrounds. Knowledge transfer involves 'the process through which one unit is affected by the experience of another' (ARGOTE and INGRAM, 2000: 151). Although some of the work on knowledge transfer has focused on the evidence or knowledge, more recent work expands the view to draw greater attention to the context and process of knowledge transfer (FITZGERALD et al., 2002; RYCROFT-MALONE et al., 2004a, 2004b).

Analyzing the global scenery, we can see that with the technology advancement the market is becoming more competitive, causing companies need a competitive advantage (differential competitive) to keep up in market, this advantage can be achieved through the innovation in process and services. This is a real economic and technology dispute that is hard to face for some countries, mainly those in development like Brazil.

In this context, earn highlights the existence of several mechanisms of knowledge transfer, like the firm creation from search results, appointed academic spin-offs.

Almeida and Mello (2009) conducted a case study about the spin-offs academics (SOA's) in 14 companies incubated or graduates in technological incubators COPPE / UFRJ and Genesis Institute of PUC-Rio and found that companies Spin-Offs have "higher productivity of labor, work, for, among other things, perform R \& D more intensively. Are less economically vulnerable companies do not spin-offs and also more prepared for the difficulties related to the management 
Independent Journal of Management \& Production (IJM\&P) ISSN: 2236-269X

of the company."

Due these facts, technology transfer and partnerships between universities and companies have been growing in recent years, as universities are the source of current scientific knowledge closer to reality for most companies, and also generate a more natural partnership taking into account they do not compete. Today universities extended their teaching capabilities, through education of individuals to form organizations through entrepreneurial education and incubation programs (ETZKOWITZ, 2009).

To Segatto-Mendes (2001) 'universities and companies cooperation is an instrument of cooperative research between public and private business institutions with research institutions and universities, in a collective effort to develop new technological knowledge that will serve to expand the scientific knowledge and for development and improvement of new products.

This study aimed realize a literature review about technology transfer from university to technology based companies focusing spin-offs, extending the argumentation of their potentials.

This research is justified by the fact that transfer of associated technologies such as spin-offs generate economic and social development because, according to Araújo et al (2005): the creation of academic spin-offs generate high added value; various jobs for people with higher training; attracts investments in the development of research that is highly favorable to new technologies, and to have a strong impact on the local economy. Some of these impacts are that economic activities as inputs of materials and production of technology-based companies tend to be local.

There is growing attention internationally to the importance of academic entrepreneurship via technology transfer (SIEGEL and PHAN, 2005). In different European countries, researchers have shown that there has been a substantial increase in the creation of academic spin-offs (WRIGHT et al., 2003; CLARYSSE and MORAY, 2005; MUSTAR et al., 2006).

Finally, most European universities were facing increasing numbers of students while budgets stayed the same, putting enormous pressure on research time and budgets. Together these elements induced the belief that the commercialization of IP through licenses, and spin-offs in particular, could generate a new revenue stream 
Independent Journal of Management \& Production (IJM\&P) ISSN: 2236-269X

DOI: 10.14807/ijmp.v3i2.46

v. 3, n. 2, July - December 2012

and lead to economic growth in the region.

\section{Methodology}

From the point of view of nature this research is classified as basic, to Silva and Menezes (2005) classifies as a search when basic aims to generate knowledge for the advancement of science without practical application envisaged.

In relation to how to approach the problem is qualitative research. A qualitative study describes the complexity of a given problem, analyzes the interaction of variables, understands and classifies dynamic processes (RICHARDSON, 1999).

According the aims this research is classified as exploratory, since according to Gil (1991), the exploratory nature is most appropriate when you want to deepen their knowledge in a particular subject. This study is classified as exploratory because you want to enhance the experience on the issue of technology transfer.

From the point of view of technical procedures constitutes a literature search, according to Silva and Menezes (2005) classifies as a research literature when drawn from previously published material, consisting mainly of books, journal articles and currently available material on the Internet.

\section{Theoretical Reference}

\subsection{The Technology Transfer}

WIth the end of a standard of society completely industrial, the society idea based on knowledge became strength. Facing this fact has encouraged increasingly actions that bring diferentials of Market to earn competitive advantage by enterprises.

For so much Garnica and Torkomian (2005) emphasize that the structures oriented science and technology that aims to produce knowledge and contribution to innovative processes are increasingly gaining importance. This generates the need for companies to technology transfer, an agent with the University employee.

It still Garnica and Torkomian (2005) who say that the TT's can give a variety of ways, as well as consulting, joint research, consulting, joint research, SOA's, patent licensing and services.

The mechanisms of technology transfer can be direct or indirect. The first group publications, meetings and events in general. In the second, they are creating new 
Independent Journal of Management \& Production (IJM\&P) ISSN: 2236-269X

DOI: 10.14807/ijmp.v3i2.46

v. 3, n. 2, July - December 2012

businesses - spin-offs, projects, cooperative $R \& D$ and licensing of patents (ROGERS, TAKEGAMI and YIN, 2001).

The technology transfer is many important when we talk about technology development. This is understood like a time that occur the knowledge assimilation generated in a company by another, however we know that is not all of technology trade brings a effective technology transfer, so it's necessary that the person who "receive the technology" can do by yourself.

It Lima (2004) who says that there are difficulties in the process of TT's, both between countries and between universities and university-company. He said those failures occur when clearly the receiving agent has enough skilled manpower to operate the technology in its production process, or even when there is difficulty in transmitting knowledge between the parties.

According Hruschka, Kovaleski and Silva (2005), the methodology of Technology Transfer has as its only objective assigning to knowledge that the receiver knows only play, but to acquire sufficient autonomy to improve and modernize their product, or even enable development of new products with the same level of technology. Then, even if TT is passed in prototype form, does not guarantee its production there is a transfer of skills.

According Hruschka, Kovaleski and Silva (2005), the methodology of Technology Transfer has as its only objective assigning to knowledge that the receiver knows only play, but to acquire sufficient autonomy to improve and modernize their product, or even enable development of new products with the same level of technology. Then, even if TT is passed in prototype form, does not guarantee its production there is a transfer of skills.

\subsection{Relationship between universities-companies}

Most of the literature dealing with the issue of technology transfer from research institutions to the productive sector, especially in Brazil, refers to public universities as sources of knowledge and technology from which they originate and begins the process of technology transfer (GARNICA, WIZIACK and SANTOS, 2006). Historically, most research and development in science and technology has a very strong relationship with the academic activities, especially regarding public universities and are recognized as centers of excellence in research in the country 
Independent Journal of Management \& Production (IJM\&P) ISSN: 2236-269X

(GARNICA and TORKOMIAN, 2005).

According to Oliveira and Caulliraux (2007) the relationship between universities and business can take from the quality improvement or development of a new product / service of a company unique even the creation of new industries. This relationship is a typical case where prevailing cooperation, not competition. The "environment" in which the actors act are different: firms crave profit, market share, universities aim the advancement and diffusion of knowledge. For firms, leaves "very expensive", while business, undertake new knowledge, because the gains are very low compared to the investment needed for the necessary infrastructure. Investments in $R$ \& D are justified when no scale to commercialization of new products / services and this explains why only large firms have $R \& D$ centers developed. It makes more sense in these cases "outsource" research to universities, and insert supporting the development of this new product / service in one of your programs (OLIVEIRA and CAULLIRAUX, 2007).

This environment, anchored by the increased market demand for development of new products / services and efforts by the government to make universities more autonomous and efficient, promotes collaboration between universities and companies. However, there are major difficulties in the execution of this collaboration, due to the lack of collaborative vision of both parties, which are not perceived by the parties, in most cases, the benefits that could be drawn from such relationship. Also, Oliveira and Caulliraux (2007) say it is very different natures of institutions in terms of "business" and even culturally.

The evolution of innovation systems, and the current conflict about which path should be taken in universities and industry relations are reflected in the different institutional arrangements of university-industry-government relations. First Lugas, one can distinguish a particular historical situation that may wish to label Triple Helix I. In this configuration, the state includes academy and industry guides and the relationships between them.

The second model reflects the relationship between the three organizations show a strong separation of institutional spheres with boundaries dividing them and highly limited relations between the spheres. Finally, Triple Helix III is creating an infrastructure of knowledge in terms of overlapping institutional spheres, with each 
Independent Journal of Management \& Production (IJM\&P) ISSN: 2236-269X

assuming the role of the other and with hybrid organizations emerging at the interfaces (ETZKOWITZ and LEYDESDORFF, 2000).

Triple Helix I is seen as a flawed development model. With very little room for initiatives, innovation is encouraged and not discouraged. Triple Helix II implies a policy of laissez-faire, today also called as shock therapy to reduce the state's role in Triple Helix I. One way or another, most countries and regions are currently trying to reach some sort of Triple Helix III. The common goal is to realize an innovative environment consisting of university spin-offs academics, tri-lateral initiatives for developing economies based on knowledge, strategic alliances between firms (large and small, operating in different areas and with different levels of technology ), government laboratories, and academic research groups. These mechanisms are generally encouraged but not controlled by the government (ETZKOWITZ and LEYDESDORFF, 2000), can be taken as an example of encouragement, Law No. 10.973, of December 2, 2004 that includes in one of its aspects the Constitution environment conducive to strategic partnerships between universities, technological institutes and companies.

As already discussed above, markets are increasingly competitive, which then brought the need for constant innovation to obtain a differential. For this the government introduced Law No. 10.973, of December 2, 2004, entitled "Innovation Law" which presents favorable legal and efficient development of science, technological and to encouraging innovation. "Innovation is much more than a concept or practice is a necessity, a position of need for action on the development of the country" (LACERDA, 2007).

This law also aims to increase the efficiency of the productive sector of the country so that it can be qualified in terms of technology for a competition not only internal but external too, may insert goods and services based on international standards of quality, with higher added value.

The Innovation Law revolves around three main strands: Strand I - Creation of enabling environment for strategic partnerships between universities, technological institutes and companies; Strand II - Stimulus to participation of institutions of science and technology in the innovation process; Strand III - Encouraging innovation in the company. 
Independent Journal of Management \& Production (IJM\&P) ISSN: 2236-269X

DOI: 10.14807/ijmp.v3i2.46

v. 3, n. 2, July - December 2012

The Strand I is comprised of the stimuli: a) Structuring networks and international research projects technological b) Shares of technological entrepreneurship and c) creation of incubators which of them generate characterized as SOA's business and technology parks.

It is noticed that this is biggest objective the magnification that become more agile knowledge transfer from academia to the productive sector. Accordingly, it is expected that the Law of Innovation will be the "start" of a sequence of measures that aim and environments conducive to innovation and partnerships between universities, research centers, enterprises and government for the creation and propagation business SOA.

\subsection{The process of technology transfer through spin-off}

Over the years, the technology development configured as a key element for companies to be able to achieve their goals, because they generate lower costs, increase productivity and flexible production lines, which makes their products more accessible to customers.

The diffusion of knowledge and technology transfer from universities to businesses can take various forms - spin-offs involving academic staff, licensing, contract research, consulting, mobility of students and researchers, among other modalities (WRIGHT et al. 2008).

Almeida and Mello (2009) says that technology-based firms (NTBFs) play a key role, considering the company's future because high added value to its products and services, besides having a high rate of innovative projects. In this context Nascent Technology Based Companies Source Academic (ENBT's OA) or academic spin-offs are those whose aim is to exploit the intellectual property developed in academic institutions (SHANE, 2004 and O'SHEA, 2008).

The level of tacit knowledge involved in technology developed also affects the propensity to create spin-offs. When the technology requires further development which cannot be realized in academic laboratories there is a greater tendency to create spin-offs involving the inventors to follow this development. The stage of development of technology also impacts this process, pre-established companies tend to look for technologies whose value proposition is already clear and applicability. These companies usually have an interest in making improvements on 
Independent Journal of Management \& Production (IJM\&P) ISSN: 2236-269X

pre-existing, rather than creating new products (RENAULT, 2010).

The time horizon of pre-established companies is another attribute that affects their ability to exploit technologies at an early stage, because the business results can take years to emerge. Technologies with applicability in multiple markets are more likely to generate spin-offs for their exploitation, because the pre-established companies tend to focus their resources on exploration of markets where we already operate. The value perceived by potential customers usually affects this process.

The technical advances of great relevance, strongly protected by intellectual property instruments, also favor the process of creating spin-offs, as these can be generated from a single knowledge asset that gives them a competitive advantage against companies pre-established (RENAULT, 2010). However, the size and variety of market factors are extremely relevant in decision making, because in some cases it may occur that the technology represents a radical innovation, where partnerships with existing companies that are more suitable of an investment in a company source.

However, the size and variety of market factors are extremely relevant in decision making, because in some cases it may occur that the technology represents a radical innovation, where partnerships with existing companies are more appropriate than an investment in a nascent company.

The process of creating spin-offs focusing on specific academic units, hardly being generalized to the university environment as a whole. There are several causes for the variance in the propensity to create spin-offs. These causes are not only related to the quality and relevance of research, as well as organizational factors, contextual and historical trajectory (RENAULT, 2010).

A central point in this analysis refers to political and organizational culture of universities or academic units in these research groups are located. Even in groups with a high rate of development of new technologies, the process of creating spin-offs can be reduced by the absence of an institutional policy of protection, licensing and enforcement of market knowledge generated (RENAULT, 2010).

Moreover, even among units that have policies of this nature, the different approaches can produce quite heterogeneous. Among these institutional policies may include: exclusive licensing; stake in spin-offs created; permission to unpaid 
Independent Journal of Management \& Production (IJM\&P) ISSN: 2236-269X

DOI: 10.14807/ijmp.v3i2.46

v. 3, n. 2, July - December 2012

leave for teachers interested in creating businesses; permission for use of resources (tangible and intangible) of the university, participation by minority inventors; access to funding sources in the form of seed capital.

Studies of Shane (2004) in about 1300 MIT spin-offs bring evidence that these points are important for an institutional policy of creating spin-offs of technological base to succeed.

\section{Final Remarks}

In today's society has valued knowledge as one of the major factors that provide an effective technological development, directly dependent on the formation of qualified human resources, the university then becomes a source of current scientific knowledge.

There was purpose of the article, say what is the best way to accomplish the transfer of technology, but leave the obvious role of spin-offs in accomplishing this process, its relationship with the university and the company, and also aiming to expand the discussion of their potential through a theoretical review.

It is necessary to make clear that the benefits generated by the creation of spinoffs as high value-added jobs for the population, attracting investments in $R \& D$, and as a consequence of these cited a strong impact on the local economy only happen if there is a joint action of government, universities and research institutes. Technology transfer should not be seen in a simple and timely, but as a process where the receiver needs a minimum level of training to identify, select, negotiate and acquire the necessary technology must be completely assimilate the new technology, not the mere purchase and limited sale (KOVALESKI and MATOS, 2002), but that involves a set of non-explicit knowledge. Indeed, using the new technology that is not the same master it in the first case occurs only one diffusion techniques and production methods (BARBIERI, 1990).

For this growing innovation, knowledge transfer and technology do not stop work is required with the head of the youth in general, more specifically with the young academic life enabling them to be able to identify several gaps in the market, the changes being versatile paradigms. Much of the students, especially the culture of engineering has to seek solution of problems only when they encounter one, and when they find a way out, then stop searching, this prevents the development of the 
Independent Journal of Management \& Production (IJM\&P) ISSN: 2236-269X

capacity to innovate.

We also realize that the big challenge is the technology development and its influence and impact on society that must be scientifically trained, so there is this scientific training should be unquestionably a scientific education. One cannot think technology alone product and as a result, but as design and creation, and so it is necessary not only individuals trained to think of it, but above all, education to prepare them. (HRUSCHKA, KOVALESKI and SILVA 2005)

The creation of spin-offs is an efficient transfer of knowledge generated by universities, so the debate as to its lack of patents pending, must be addressed so that consequently generate more benefits.

\section{References}

ALMEIDA, R. B.; MELLO, J. M. C. (2009) Um estudo de caso sobre um novo modelo de empreendimento: os spin-offs acadêmicos. V CONGRESO NACIONAL DE EXCELÊNCIA EM GESTÃO - Niterói.

ANDRADE, M. M. (2005) Competências requeridas pelos gestores de Instituições de ensino superior privadas: um estudo em Curitiba e região Metropolitana. 2005. $173 \mathrm{f}$. Dissertação (Mestrado em Tecnologia) - Programa de Pós-graduação em Tecnologia, Universidade Tecnológica Federal do Paraná. Curitiba.

AZEVEDO, G. C. I. (2005) Transferência de tecnologia através de spin-offs: os desafios enfrentados pela UFSCar. 2005. 136. p. Dissertação (Mestrado em Engenharia de produção)- Programa em Engenharia de Produção, Universidade Federal de São Carlos. São Carlos.

BARBIERI, J. C. (1990) Produção e transferência de tecnologia. Ed. Ática, São Paulo.

CLARYSSE, B.; MORAY N (2005); 'Universitaire spin-offs in Vlaanderen,' in Vlaams Indicatorenboek, Belgium.

CYSNE, F. P.Transferência de tecnologia entre a universidade e a indústria. Departamento de ciências da informação do centro de humanidades. UFC.

DOSS, A. A.; SEGATTO, A. P. (2010) Pesquisas cooperativas entre universidades e institutos públicos no setor agropecuário brasileiro: um estudo na Embrapa*. Revista de administração Pública - Rio de Janeiro.

ETZKOWITZ, H.; (2009) Hélice Tríplice: universidade, indústria e governo: inovação em movimento. Porto Alegre: EDIPUCRS.

ETZKOWITZ, H.; LEYDESDORFF, L.; The dynamics of innovation: from National Systems and "Mode2" to a Triple Helix of university-industrygovernment relations.

GARNICA, L. A.; TORKOMIAN, A. L. V. (2005) Transferência de tecnologia universidade-empresa: fortalecimento de um modelo de cooperação através da propriedade intelectual. XII SIMPEP - Bauru. 
GARNICA, L. A.; WIZIAK, N. K. L; SANTOS, S. A. (2006) Transferência de tecnologia por meio da criação de empresas de base tecnológica: um estudo multicaso de licenciamento de patentes da Embrapa e UFSCar. XXVI ENEGEP Fortaleza.

GIL, A. (1999) Como elaborar projetos de pesquisa. São Paulo: Atlas.

HRUSCKA, J.; KOVALESKI, J. L.; SILVA, S. A. O. (2005) Transferência de Tecnologia: trabalhos de Diplomação como Mecanismo de Interação Universidade Empresa. XXV ENEGEP - Porto Alegre.

JOHNSON, B.; LUNDVALL, B. A. (2005) Promovendo sistemas de inovação como resposta à economia do aprendizado crescentemente globalizada. In: Lastres, H. M. M.; CASSIOLATO, J. E. ARROIO, A. (ORGS.); Conhecimento, sistemas de inovação e desenvolvimento. Rio de Janeiro: UFRJ, Contraponto.

KOVALESKI, J. L.; MATOS, E. A. S. A. (2002) Metodologia de negociação entre universidade - indústria - governo. In: SIMPÓSIO DE GESTÃO DA INOVAÇÃO TECNOLÓGICA, 22, 2002, Salvador. Anais... Salvador: USP/ PGT, p. 1-12.

LACERDA, N. (2011) Focalizando a Lei de Inovação. Disponível em: <http://www.fundocriatec.com.br/arquivos_internos/focalizandoaleideinovacao.pdf> Acesso em setembro de 2011.

LIMA, I. A. (2004) Estrutura de Referência para a Transferência de Tecnologia no âmbito da Cooperação Universidade-Empresa: Estudo de Caso no Cefet-PR. Florianópolis, 2004. 202 f. Tese (Doutorado em Engenharia de Produção) Programa de Pós-Graduação em Engenharia de Produção, Universidade Federal de Santa Catarina.

MARQUES, E. B.; KOVALESKI, J. L.; TEBCHERANI, S. M. (2007) A captação de recursos financeiros via fomentos públicos para o desenvolvimento de pequenas empresas de base tecnológica Estudo de Caso. In: XIX SIMPÓSIO DE ENGENHARIA DE PRODUÇÂO, Bauru.

MCTI - MINISTÉRIO DA CIÊNCIA, TECNOLOGIA E INOVAÇÃO. Lei de Inovação. Disponível em < http://www.mct.gov.br/index.php/content/view/8477.html>. Acesso em outubro de 2011.

MUSTAR, P., RENAULT M., COLOMBO M., PIVA E., FONTES M., LOCKETT, M A. WRIGHT, B. CLARYSSE; MORAY N. (2006), 'Conceptualising the heterogeneity of research-based spin-offs: A multi-dimensional taxonomy,' Research Policy, 35(2), 289-308.

OLIVEIRA, A. R.; CAULLIRAUX, H. M. (2007) Uma proposta de modelo cooperativista que relacione universidade e empresa. XXVII ENEGEP - Foz do Iguaçu.

O'SHEA, R.P, CHUGH, H., ALLEN, T. (2007) Determinants and Consequences of University Spinoff Activity: A Conceptual Framework. Technol Transfer.

RENAULT, T. B.; A (2010) criação de spin-offs acadêmicos: caso coppe/ufr.. Rio de Janeiro: $2010.108 \mathrm{f}$. Tese (Doutorado) - COPPE, Universidade Federal do Rio de janeiro, Rio de janeiro.

RICHARDSON, R. J. (1999) Pesquisa Social: métodos e técnicas. 3 ed. São Paulo: Atlas, 1999. 
ROGERS, E. M. ; TAKEGAMI, S. \& YIN, J. (2001) Lessons learned about technology transfer. Technovation. V. 21. p. 253-261.

RYCROFT-MALONE, J., HARVEY, G., SEERS, K., KITSON, A., MCCORMACK, B., \& TICTCHEN, A. (2004a) An exploration of the factors that influence the implementation of evidence into practice. Journal of Clinical Nursing, v. 13, p. 913924.

RYCROFT-MALONE, J., SEERS, K., TITCHEN, A., HARVEY, G., KITSON, A. \& MCCORMACK, B. (2004b) What counts as evidence in evidence-based practice? Journal of Advanced Nursing, v. 47, n. 1, p. 81-90.

SHANE, S. (2004) Academic Entrepreneurship. University Spinoffs and Wealth Creation. Case Western Reserve University. New Horizons in Entrepreneurship. Chaeltenhan, UK.

SIEGEL, D. S.; P. PHAN (2005); 'Analyzing the effectiveness of university technology transfer: implications for entrepreneurship education,' in Gary Liebcap (ed.), Advances in the Study of Entrepreneurship, Innovation, and Economic Growth, Vol. 16, Elsevier Science/JAI Press: Amsterdam, p. 1-38.

SILVA, E. L.; MENEZES, E. M. (2005) Metodologia da pesquisa e elaboração de dissertação. Florianópolis, Laboratório de Ensino à Distância da UFSC. 2005. Disponível em: < http://www.eps.ufsc.br/ppgep.html >. Acesso em julho de 2011.

SoUZA, C. G. (2009) Análise dos padrões de depósitos de patentes de universidades brasileiras. XXIX ENEGEP - Salvador.

WRIGHT, M., BINKS M.; VOHORA A.; LOCKETT A. (2003) UK Technology Transfer Survey. Financial Year 2002. NUBS/U NICO/AURIL.

WRIGHT, M.; CLARYSSE, B.; LOCKETT, A. KNOCKAERT, M. (2008) Mid-range universities" linkages with industry: Knowledge types and the role of intermediaries. Research Policy, v. 37, p. 1205-1223.

ZANLUCHI, J. B.; GONÇALO, C. R. (2007) O estágio de desenvolvimento da pesquisa aplicada através da relação universidade-empresa. XXVII ENEGEP - Foz do Iguaçu. 